\title{
Pola distribusi dan performansi lokasi hotel di Kecamatan Depok, Kabupaten Sleman
}

\author{
Icha Pajrisa Dwi Putri*, Joni Purwohandoyo* \\ * Prodi Pembangunan Wilayah, Departemen Geografi Pembangunan, Fakultas \\ Geografi, Universitas Gadjah Mada
}

\begin{tabular}{l}
\hline \hline INFO ARTIKEL \\
\hline Riwayat Artikel: \\
Dikirim: $13-9-2018$ \\
Disetujui: $24-5-2019$ \\
Diterbitkan: $30-6-2019$
\end{tabular}

Kata kunci:

Hotel; Distribution Pattern; Location Performance
Alamat Korespondensi:

Icha Pajrisa Dwi Putri

Pembangunan Wilayah

Universitas Gadjah Mada

Bulaksumur, Yogyakarta, 55281

\section{ABSTRAK}

Abstract: The purpose of this research are to analyze the distribution pattern and the location performance of hotel in Depok regency. The population in this research are all of hotel in Depok regency which is divided in to non star hotel, hotel star 1, hotel star 2, hotel star 3, hotel star 4 and hotel star 5. The data analysis method uses spatial analysis and statistic descriptive analysis. The result of this research shows that the spatial distribution of hotel in Depok regency is clustering. The clustering of hotel divided in to 4 classes there are hotel which associate with Laksda Adi Sucipto street, Ringroad Utara street, colleage and the city forest. Hotel which have the best performance are located in Laksda Adi Sucipto street with the characteristc non-star hotel. Based on the result of this research show there is no correlation between spatial distribution and location performance hotel.

Abstrak: Penelitian ini bertujuan untuk menganalisis pola persebaran hotel di Kecamatan Depok dan menganalisis performansi lokasi hotel di Kecamatan Depok. Populasi dalam penelitian ini adalah semua hotel di Kecamatan Depok yang terdiri dari hotel kelas non-bintang, bintang 1, bintang 2, bintang 3, bintang 4 dan bintang 5 . Metode analisis yang digunakan dalam penelitian ini adalah analisis spasial dan analisis statistik deskriptif. Hasil penelitian ini menunjukkan bahwa hotel yang berada di Kecamatan Depok memiliki pola distribusi hotel yang mengelompok. Secara spasial pengelompokkan pola distribusi hotel di Kecamatan Depok terdiri dari hotel yang berasosiasi dengan Jalan Ringroad, Jalan Laksda Adi Sucipto, Perguruan Tinggi dan Hutan Kota. Hotel yang memiliki performansi lokasi tertinggi memiliki karaktertistik berupa hotel non-bintang dan berada di Jalan Laksda Adi Sucipto. Berdasarkan hasil penelitian ini tidak ada hubungan antara pola distribusi hotel dan performansi lokasi hotel.

This is an open access article under the CC-BY-SA license. 
Jurnal Pendidikan Geografi:

Kajian, Teori, dan Praktik dalam Bidang Pendidikan dan Ilmu Geografi

Tahun 24, Nomor 2, Jun 2019, Hal 85-97

E-mail: Ichapajrisa96@gmail.com

\section{PENDAHULUAN}

Provinsi Daerah Istimewa Yogyakarta (DIY) merupakan provinsi yang memiliki jumlah wisatawan yang terus meningkat setiap tahunnya. Berdasarkan data BPS (2016) laju pertumbuhan wisatawan pada tahun 2012 sampai dengan 2016 di Provinsi DIY sebesar 17\%. Menurut Inskeep (1991) prasarana akomodasi merupakan kebutuhan utama wisatawan karena proporsi pengeluaran terbesar dari wisatawan dipakai untuk kebutuhan penginapan, makan dan minum. Oleh karena itu, bertambahnya jumlah wisatawan harus diiringi dengan bertambahnya jumlah hotel di Provinsi DIY.

Kota Yogyakarta merupakan wilayah yang memiliki jumlah hotel terbanyak pada tahun 2013 yaitu sebanyak 401 hotel. Maraknya pembanguan hotel di Kecamatan Depok menjadi pertimbangan pemerintah Kota Yogyakarta mengeluarkan Peraturan Walikota (Perwal) nomor 77 tahun 2013 tentang pengendalian pembangunan hotel. Peraturan ini berisikan moratorium perizinan pembangunan hotel di Kota Yogyakarta sampai dengan tahun 2019.

Dengan ditetapkannya peraturan walikota tersebut, para investor memilih lokasi yang terdekat dengan Kota Yogyakarta yaitu Kecamatan Depok. Menurut Antariksa (2015) pertumbuhan hotel dalam rentang waktu 2010 sampai dengan 2013 memiliki kecenderungan pembangunan di sisi utara Kota Yogyakarta. Berdasarkan data BPS (2016) pada tahun 2011 jumlah hotel di Kecamatan Depok terdiri dari 40 hotel sedangkan pada tahun 2016 jumlah hotel di Kecamatan Depok sebanyak 52 hotel.

Berdasarkan penjabaran diatas maka pertumbuhan hotel yang terjadi di Kecamatan Depok perlu dilakukan analisis mendalam pada pola distribusi hotel. Pola distribusi hotel memiliki pengaruh yang berbeda terhadap efisiensi dan efektifitas pendapatan hotel (Piero Signes et al, 2014). Hotel yang memiliki distribusi mengelompok memiliki tingkat pendapatan yang lebih besar dibandingka dengan hotel dengan pola distribusi lainnya. Pola distribusi hotel dapat dikategorikan menjadi 3 model berupa theoretical, empircal model dan operational model (Yang, 2014). Oleh karena itu, perlu dilakukan telaah mengenai pola distribusi hotel di Kecamatan Depok.

Kajian lain yang penting dilakukan pada hotel di Kecamatan Depok adalah mengenai performansi lokasi hotel. Performansi lokasi hotel sangat mempengaruhi tata ruang kawasan wisata. Menurut Irawan dan Baiquni (2011) salah satu indikator pariwisata yang berkelanjutan adalah hotel yang berlokasi pada tata ruang kawasan wisata yang baik. Hotel yang memiliki kawasan wisata yang baik merupakan hotel yang berada di zona tata ruang yang diizinkan untuk dilakukan kegiatan wisata. Dampak yang diberikan oleh lokasi hotel yang sesuai dengan tata ruang mampu memberi intervensi positif terhadap peningkatan kesejahteraan kehidupan sosial dan lingkunga di masyarakat sekitarnya (Rustiadi, 2009).

\section{METODE}

Penelitian ini menggunakan data sekunder dan data primer. Data sekunder terdiri dari dbata yang diperoleh dari instansi terkait dan data primer diperoleh dari hasil wawancara dengan pengelola hotel. Populasi dalam penelitian ini adalah seluruh hotel yang ada di Kecamatan Depok yang terdiri dari hotel non-bintang, hotel bintang 1, hotel bintang 2 hotel bintang 3, hotel bintang 4 dan hotel bintang 5. Teknik pengolahan data yang digunakan untuk menganalisis pola distribusi lokasi hotel adalah menggunakan teknik analisis tetangga tedekat. Data yang digunakan untuk menganalisis tetangga terdekat adalah data hasil plotting di lapangan. Teknik pengolahan data yang digunakan 
Jurnal Pendidikan Geografi:

Kajian, Teori, dan Praktik dalam Bidang Pendidikan dan Ilmu Geografi

Tahun 24, Nomor 2, Jun 2019, Hal 85-97

untuk menganalisis performansi lokasi hotel menggunakan 2 (dua) teknik yaitu dengan AHP (Analytical Hierarchy Process) dan perhitungan statistik dengan teknik ranking. Metode analisis data yang digunakan dalam penelitian ini adalah analisis spasial dan analisis statistik deskriptif. Indikator dan variabel yang digunakan untuk menganalisis performansi lokasi hotel terdapat pada Tabel 1 .

Tabel 1. Indikator dan Variabel dalam Perhitungan Performansi Lokasi Hotel

\begin{tabular}{ccc}
\hline No & Indikator & Variabel \\
\hline 1 & Atribut Lokasi Hotel & Aksesibilitas terhadap ODTW (Obyek Daya Tarik Wisata) \\
& & Aksesibilitas terhadap sarana transportasi \\
& & Aksesibilitas terhadap CBS (Central Business Services) \\
2 & Peraturan Daerah & Kesesuain dengan peraturan tata ruang \\
& & Harga Lahan \\
3 & Karakteristik Hotel & Lama rata-rata pengunjung menginap \\
& Jasa Publik Sekitar & Jumlah fasilitas layanan hotel \\
4 & Hotel & Jarak terhadap pelayanan pendidikan \\
& & Jarak terhadap pelayanan kesehatan \\
& & Jarak terhadap pelayanan pasar \\
\hline
\end{tabular}

Sumber: Hasil Penelusuran Peneliti, 2018

\section{HASIL DAN PEMBAHASAN}

Hotel yang berada di Kecamtan Depok terdiri dari 94 hotel. Berdasarkan hasil perhitungan analisis tetangga terdekat, terlihat bahwa nearest neighbor ratio (Nilai $\mathrm{T}$ ) sebesar 0,75292. Menurut Sumaatmadja (1988) dalam Muta'ali (2015) apabila nilai T lebih dari 0 dan mendekati $1 \quad(0<\mathrm{T} \leq 1)$ menunjukkan pola menyebar secara acak (random) sedangkan nilai $\mathrm{T}$ lebih dari 1 dan mendekati $2,15(1<\mathrm{T} \leq 2,15)$ menunjukkan pola sebaran yang terjadi adalah seragam (uniform). Berdasarkan penjabaran tersebut nilai $\mathrm{T}$ tergolong dalam kategori yang mendekati nilai 0 yang berarti memiliki pola distribusi yang mengelompok (clustered).

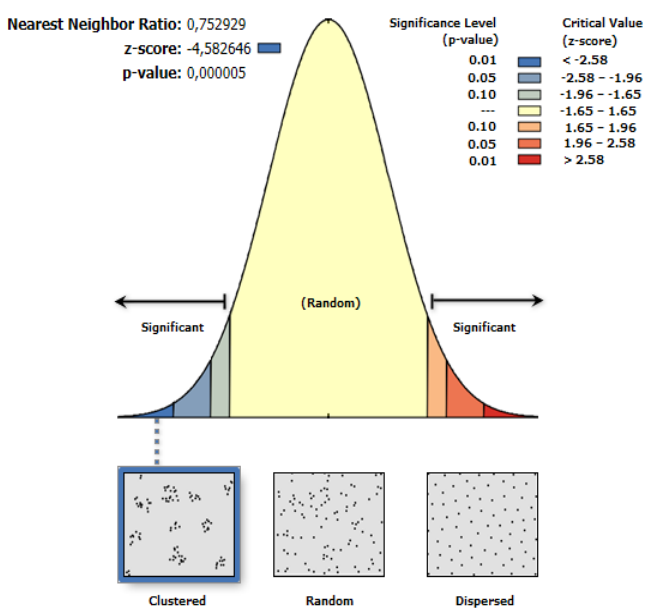

Gambar 1. Ilustrasi Hasil Perhitungan Analisis Tetangga Terdekat

Berdasarkan Gambar 1, diperoleh nilai z-score dan p-value. Nilai z-score sebesar 4,582646 dan p-value sebesar 0,000005 yang berarti bahwa hasil perhitungan yang diperoleh memiliki tingkat validitas yang sangat tinggi dan dapat dipercaya. Secara keruangan pola persebaran hotel dari aspek sifat persebaran dibedakan menjadi 4 pola yang dapat dilihat pada gambar 2, yaitu pola persebaran hotel yang mengelompok tidak teratur dengan hutan kota, pola persebaran lokasi hotel yang mengelompok tidak teratur di Jalan Laksda Adi Sucipto-Jalan Raya Solo Yogyakarta, pola persebaran hotel yang 
Jurnal Pendidikan Geografi:

Kajian, Teori, dan Praktik dalam Bidang Pendidikan dan Ilmu Geografi

Tahun 24, Nomor 2, Jun 2019, Hal 85-97

mengelompok tidak teratur di Jalan Ringroad dan pola persebaran lokasi hotel yang mengelompok tidak teratur dengan perguruan tinggi.

Hotel yang berada di lokasi yang berasosisi dengan hutan kota di dominasi oleh hotel non-bintang dengan persentase sebesar $100 \%$. Hotel yang berasosiasi dengan Jalan Laksda Adi Sucipto terdapat sebanyak 42 hotel dengan persentase hotel terbanyak adalah hotel bintang 3 sebesar 31\%. Hotel yang berasosiasi dengan Jalan Ringroad Utara terdapat sebanyak 24 hotel dan 50\% diantaranya merupakan hotel non-bintang. Hotel yang berasosiasi dengan perguruan tinggi sebanyak 26 hotel yang mana 9 atau sekitar $27 \%$ diantaranya merupakan hotel non-bintang.

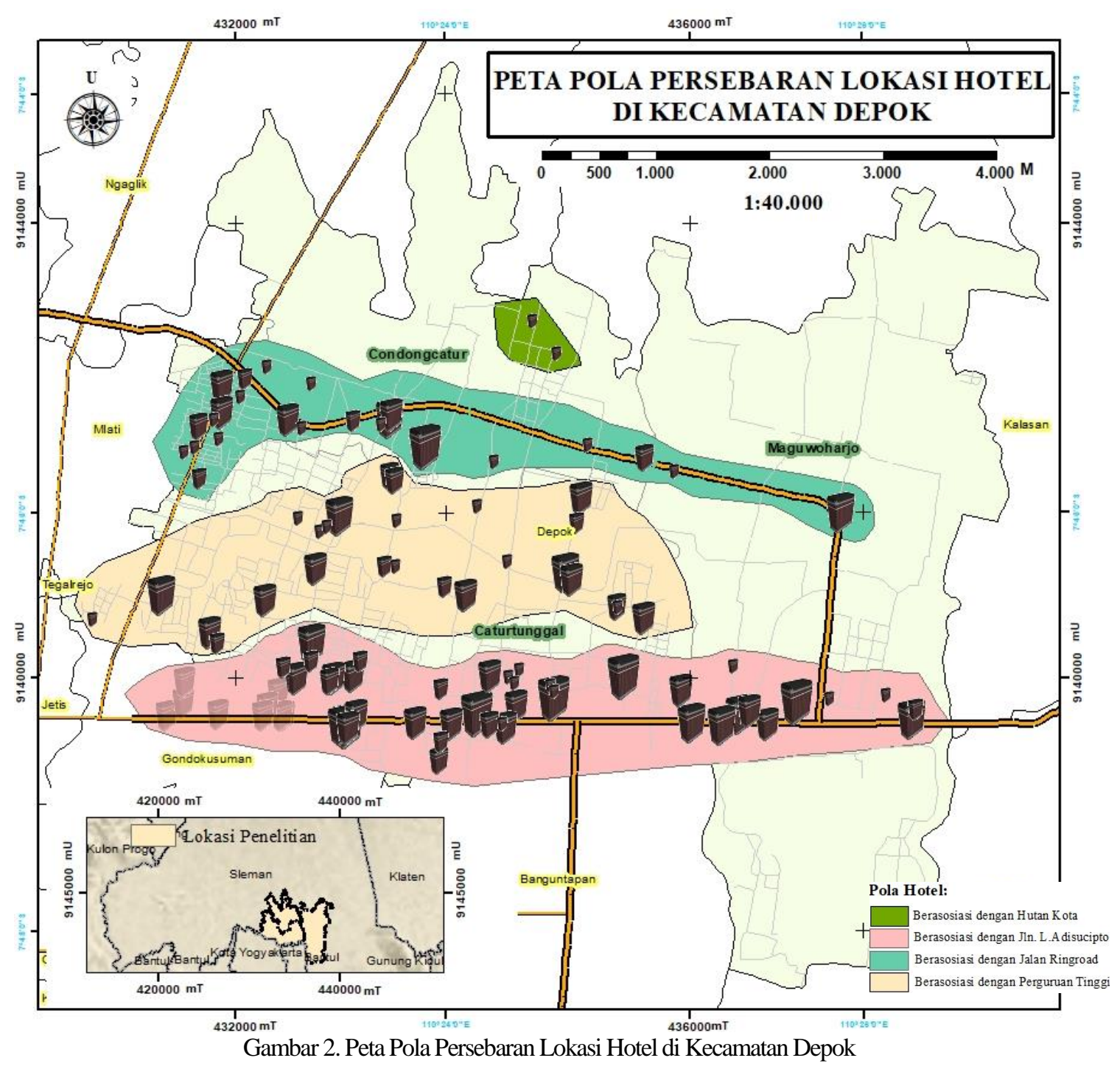

Model lokasi hotel terbagi menjadi 3 klasifikasi yaitu teoritis, empiris dan operasional (Yang, 2014). Model teoritis merupakan model yang menjelaskan proses terbentuknya hotel berdasarkan teori lokasi yang suda ada. Model teoritis dikategorikan menjadi 4 tipe yaitu model kota wisata-sejarah (tourist-historic city model), model monosentris (monocentrics model), model aglomerasi, dan model multidimensi (Yang, 2014). Berdasarkan Gambar 2 diatas dapat disimpulkan bahwa lokasi hotel yang terbentuk di Kecamatan Depok memiliki karakteristik yang sesuai dengan model kota wisata sejarah. Pada Gambar 2 terlihat bahwa hotel yang memiliki segmen lokasi di kota tradisional 
Jurnal Pendidikan Geografi:

Kajian, Teori, dan Praktik dalam Bidang Pendidikan dan Ilmu Geografi

Tahun 24, Nomor 2, Jun 2019, Hal 85-97

merupakan hotel yang terletak di luar jalan arteri dan jalan kolektor dan di dominasi oleh hotel non-bintang seperti hotel A60 (432266,773661; 9142741,21952), A61 $(432663,19118 ; \quad 9142590,88162), \quad$ A65 (434615,185341; 9143144,32937), A29 (434818,707766; 9142854,40308), A33 (433227,536;9140181,614), A82 (437726,785653; 9139844,50117), A6 (437989,379367; 9139717,38012). Hotel yang ada di Kecamatan Depok tidak ada yang berlokasi di segmen dekat stasiun kereta api. Hotel yang berlokasi di segmen jalan utama di dominasi oleh hotel berbintang 3, hotel berbintang 4 dan hotel berbintang 5 . Hotel yang berlokasi di segmen dekat bandara di dominasi oleh hotel bintang. Hotel yang berada di segmen lokasi yang memiliki aksesibilitas yang tinggi merupakan hotel bintang dan non-bintang dengan jumlah proporsi yang sama. Hotel yang memiliki aksesibilitas yang baik merupakan hotel yang berada di pusat-pusat pelayanan seperti daerah Seturan, Kaliurang, dan Gejayan. Di samping itu, hotel di segmen pinggiran kota adalah hotel non-bintang seperti A60, A61, A65 dan A29.

Hasil ini diperkuat oleh penelitian yang dilakukan sebelumnya oleh Timothy dan Wall (1997), yang mengatakan bahwa hotel di Kecamatan Depok memiliki karakteristik yang sesuai dengan model kota wisata-sejarah (tourist-historic city model). Gambar 3 merupakan peta persebaran lokasi hotel di Kota Yogyakarta dan sekitarnya pada tahun 1997. Gambar 3 menjelaskan bahwa pada tahun 1997 hotel di Kota Yogyakarta yang berlokasi dekat dengan terminal di dominasi oleh hotel non-bintang. Hotel yang berasosiasi dengan Jalan Malioboro didominasi oleh hotel berbintang. Selain itu, menurut Timothy dan Wall (1997) hotel yang berada di jalan utama menuju bandara di dominasi oleh hotel bintang.

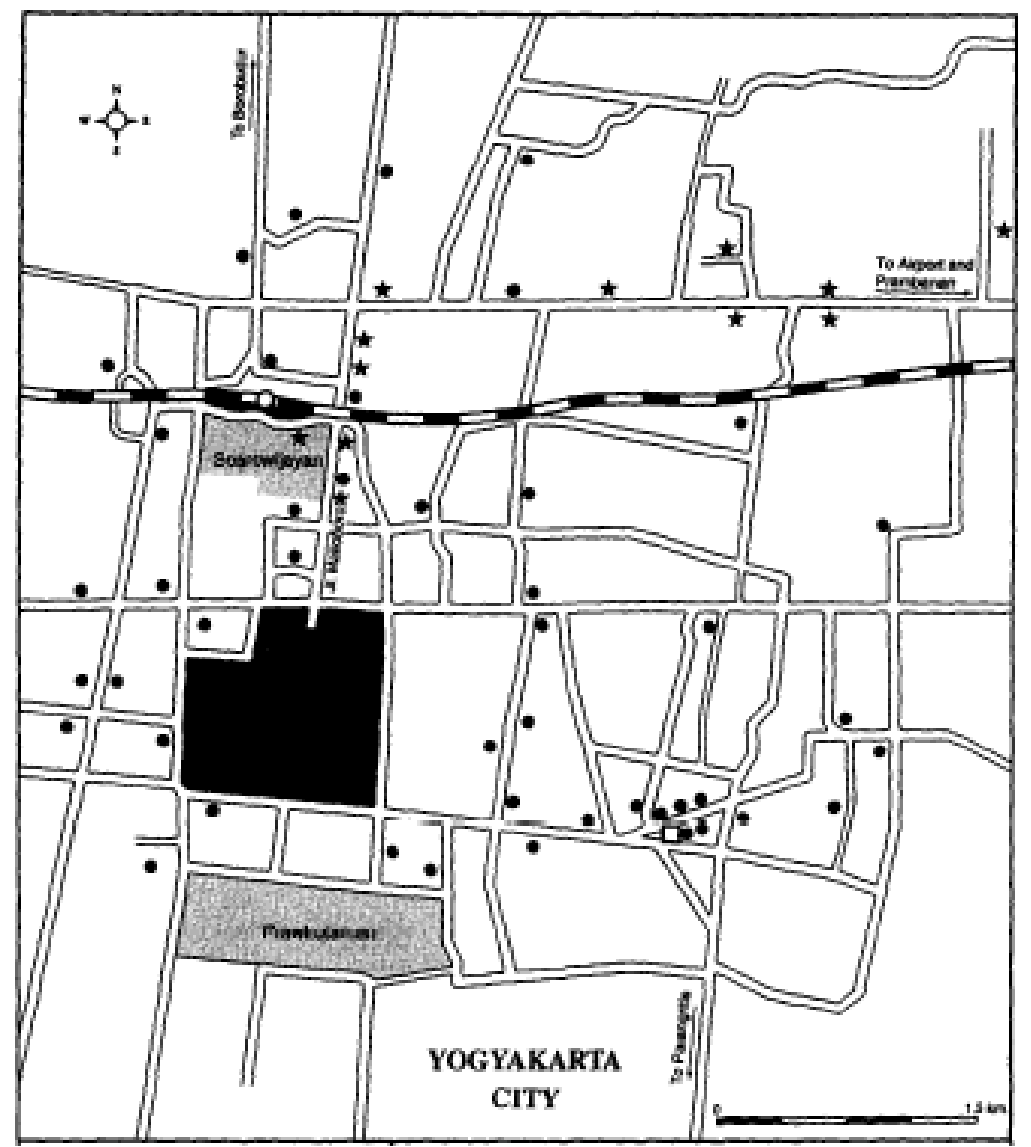

Gambar 3. Peta Persebaran Lokasi Hotel di Kota Yogyakarta dan Sekitarnya Tahun 1997 Sumber: Timothy dan Wall, 1997 
Jurnal Pendidikan Geografi:

Kajian, Teori, dan Praktik dalam Bidang Pendidikan dan Ilmu Geografi

Tahun 24, Nomor 2, Jun 2019, Hal 85-97

Perhitungan performansi lokasi hotel menggunakan 4 variabel berupa atribut lokasi, peraturan daerah, karakteristik hotel dan jasa publik sekitar hotel. Masing-masing variabel tersebut dibagi menjadi beberapa indikator yang berbeda yang dapat dilihat pada Tabel 2 . Berdasarkan hasil perhitungan AHP yang telah dilakukan, maka diperoleh bahwa variabel terpenting dari perhitungan bobot performansi lokasi hotel adalah peraturan daerah. Peraturan daerah merupakan salah satu variabel terpenting karena menurut B.L. MacCarthy dan W. Atthirawong (2003) salah satu variabel utama yang mempengaruhi penentuan lokasi hotel internasional adalah peraturan daerah. Hasil ini juga diperkuat oleh Saracli (2015) yang mengatakan bahwa faktor lingkungan yang terdiri dari subfaktor keterdekatan dengan mata air dan subfaktor tata ruang kota merupakan faktor terpenting dalam melakukan pemilihan lokasi hotel.

Pada variabel atribut lokasi indikator terpenting adalah aksesibilitas terhadap objek daya tarik wisata (ODTW).Variabel lokasi merupakan variabel yang menggambarkan seberapa besar tingkat aksesibilitas hotel dalam mendukung kegiatan dan aktivitas wisatawan. Atribut lokasi hotel digunakan sebagai variabel karena atribut lokasi merupakan faktor terpenting kedua setelah faktor ekonomi yang dapat mempengaruhi tingkat investasi pada suatu hotel. Hal ini disebabkan karena aktivitas dan kegiatan wisatawan sangat dipengaruhi oleh jarak hotel terhadap suatu objek lokasi (Newell et al, 2005). Objek lokasi yang digunakan dalam perhitungan ini terdiri dari 3 (tiga) objek yaitu objek sarana transportasi, objek wisata dan objek central business services (CBS).

Pada variabel peraturan daerah indikator terpenting adalah kesesuaian lokasi terhadap kebijakan tata ruang. Pada variabel karakteristik lokasi hotel indikator terpenting adalah jumlah layanan hotel. Jumlah fasilitas pelayanan pada suatu hotel merupakan salah satu faktor yang mempengaruhi wisatawan dalam melakukan pemilihan lokasi hotel (Yang, 2012). Jumlah layanan hotel adalah data yang menggambarkan seberapa banyak jumlah fasilitas yang ditawarkan oleh hotel tersebut. Pada variabel jasa publik indikator yang terpenting adalah aksesibilitas terhadap pelayanan kesehatan. Menurut Poldrugovac (2017) hotel yang memimliki keterdekatan dengan rumah sakit akan memiliki nilai jual yang lebih tinggi dibandingkan dengan hotel yang berada di lokasi yang jauh dari rumah sakit.

Tabel 2. Perhitungan AHP

\begin{tabular}{cccc}
\hline $\begin{array}{c}\text { Variabel Strategi } \\
\text { Performansi Lokasi } \\
\text { Hotel }\end{array}$ & Bobot & Indikator & $\begin{array}{c}\text { Bo- } \\
\text { bot }\end{array}$ \\
\hline Atribut Lokasi & 2,6924 & Aksesibilitas terhadap objek daya tarik wisata (ODTW) & 8,524 \\
& & $\begin{array}{c}\text { Aksesibilitas terhadap sarana transportasi (stasiun dan bandara) } \\
\text { Aksesibilitas terhadap CBS (central business services) }\end{array}$ & 2,433 \\
Peraturan Daerah & 9,5798 & Kesesuaian lokasi dengan peraturan pemerintah & 7,082 \\
& & Harga lahan & 1,164 \\
Karakteristik Hotel & 5,61671 & Lama rata-rata pengunjung menginap & 1,949 \\
& & Jumlah fasilitas layanan milik hotel & 2,052 \\
Jasa Publik sekitar & 3,54023 & Jarak terhadap perguruan tinggi & 1,981 \\
hotel & & Jarak terhadap rumah sakit & 6,758 \\
& & Jarak terhadap mall & 3,072 \\
\hline
\end{tabular}

Sumber: Pengolahan data primer, 2018

Kesuksesan investasi di bidang industri perhotelan sangat bergantung pada faktor lokasi (Yang, 2014). Hal ini disebabkan karena performansi lokasi hotel yang strategis berhubungan dengan permintaan terhadap akomodasi yang tinggi dan permintaan terhadap kebutuhan kamar hotel yang meningkat (Yang, 2014). Oleh sebab itu, analisis terhadap lokasi hotel perlu dilakukan supaya wisatawan mendapatkan informasi mengenai 
Jurnal Pendidikan Geografi:

Kajian, Teori, dan Praktik dalam Bidang Pendidikan dan Ilmu Geografi

Tahun 24, Nomor 2, Jun 2019, Hal 85-97

performansi lokasi hotel yang strategis karena lokasi hotel merupakan salah satu faktor yang mempengaruhi pergerakan wisatawan (Shoval et al, 2011). Perhitungan performansi lokasi hotel terdiri dari 4 variabel. Variabel atribut lokasi terdiri dari indikator sarana transportasi, obyek wisata dan central business services. Untuk variabel atribut lokasi data yang digunakan merupakan data jarak antara hotel ke 3 lokasi tersebut. Variabel peraturan daerah terbagi menjadi 2 indikator yaitu kesesuaian terhadap tata ruang dan harga lahan. Harga lahan merupakan data zona nilai tanah yang diperoleh dari BPN Sleman. Variabel karakteristik hotel terdiri dari 2 (dua) indikator berupa lama rata-rata pengunjung menginap dan jumlah layanan hotel. Kedua indikator inni diperoleh dari hasil wawancara dengan pengelola hotel. Variabel jasa publik sekitar hotel terdiri dari 3 indikator yaitu perguruan tinggi, rumah sakit dan mall. Data yang digunakan merupakan jarak antar hotel ke 3 lokasi obyek tersebut.

Berdasarkan hasil perhitungan nilai performansi lokasi hotel 3 (tiga) tertinggi secara berurutan adalah hotel A82(437726,785653; 9139844,50117), A84 (431631,222234; 9142029,52614), dan A2 (431802,444928; 9142273,44319). Hotel A82 memiliki nilai performansi lokasi sebesar 150,60 yang merupakan akumulasi dari indikator atribut lokasi dengan nilai 15,29, indikator peraturan daerah dengan nilai 75,82, indikator karakteristik hotel dengan nilai 45,47 dan indikator jasa publik sekitar hotel dengan nilai 14,02. Hotel ini memiliki nilai performansi tertinggi disebabkan karena beberapa faktor yaitu hotel A82 berlokasi dekat dengan bandara. Di samping itu, berdasarkan Peraturan Bupati Sleman Nomor 44 Tahun 2017 tentang Pengendalian Pemantaan Ruang, hotel A82 terletak di zona yang berizin untuk dilakukan kegiatan pemanfaatan usaha hotel. Faktor lainnya yang menunjang hotel A82 adalah karena hotel ini memiliki jumlah layanan hotel sebanyak 22 fasilitas sehingga menyebabkan lama rata-rata wisatawan yang menginap kurang lebih 3 malam dengan rata-rata okupansi sebesar 50,6\%.

Hotel yang memiliki nilai performansi lokasi tertinggi kedua adalah A84 dengan nilai performansi lokasi sebesar 150,51 yang merupakan akumulasi nilai dari indikator atribut lokasi sebesar 17,89, indikator peraturan daerah sebesar 79,48, indikator karakteristik hotel sebesar 27,31 dan indikator jasa memiliki nilai sebesar 25,82. Hotel A84 memiliki nilai performansi lokasi hotel yang tinggi disebabkan karena terletak di zona yang berizin untuk dilakukan kegiatan pemanfaatan lokasi hotel dan karena lokasi hotel A84 berdekatan dengan perguruan tinggi dan fasilitas pelayanan kesehatan.

Hotel yang memiliki nilai performansi lokasi tertinggi ketiga adalah A2 dengan nilai performansi sebesar 150,02 yang merupakan akumulasi dari nilai indikator atribut lokasi sebesar 17,66, indikator peraturan daerah sebesar 86,21, indikator karakteristik hotel sebesar 20,48 dan indikator jasa publik sekitar hotel sebesar 25,66. Faktor yang menyebabkan hotel A2 memiliki nilai performansi lokasi yang tinggi adalah karena hotel A2 terletak pada zona yang diizinkan untuk pemanfaatan lokasi hotel dan lokasi A2 memiliki zona nilai tanah yang tergolong tinggi dibandingkan dengan zona nilai tanah hotel lainnya.

Hotel yang memiliki nilai performansi lokasi 3 (tiga) terendah secara berurutan adalah hotel A31(435005,257335; 9141366,13404), A6 (437989,379367; 9139717,38012) dan A50 (433402,043; 9141734,355). Hotel yang memiliki nilai performansi lokasi terendah adalah A31 dengan nilai 59,60 yang merupakan akumulasi dari nilai indikator atribut lokasi sebesar 11,56, indikator peraturan daerah sebesar 11,33, indikator karakteristik hotel sebesar 9,48 dan indikator jasa publik sekitar hotel sebesar 27,23. Hotel A31 memiliki nilai performansi lokasi yang rendah disebabkan karena hotel A31 terletak pada zona yang tidak diizinkan untuk dimanfaatkan sebagai usaha hotel. Selain itu, tingkat okupansi di hotel A2 tergolong rendah dan fasilitas yang diimiliki sedikit. 
Hotel yang memiliki nilai performansi lokasi terendah kedua adalah A6 dengan nilai 62,42 yang merupakan akumulasi dari nilai indikator atribut lokasi sebesar 10,74, indikator peraturan daerah sebesar 30,82, indikator karakteristik hotel sebesar 17,32 dan indikator jasa publik sekitar hotel sebesar 3,54. Hotel A6 memiliki nilai performansi yang rendah karena lokasi hotel yang berada cukup jauh dari pelayanan pendidikan dan kesehatan. Hotel yang memiliki nilai performansi lokasi terendah ketiga adalah A50 dengan nilai 68,49 yang merupakan akumulasi dari nilai indikator atribut lokasi sebesar 16,29 , indikator peraturan daerah sebesar 9,58, indikator karakteristik hotel sebesar 13,15 dan indikator jasa publik sekitar hotel sebesar 29,48. Hotel A50 memiliki nilai performansi yang rendah karena lokasi hotel berada pada zona yang tidak diizinkan untuk dimanfaatkan sebagai usaha hotel dan lokasi hotel A50 berada di zona nilai tanah yang tergolong rendah. Adapun lokasi hotel yang memiliki nilai performansi lokasi yang tertinggi dan terendah dapat dilihat pada Gambar 4 sebagai berikut.

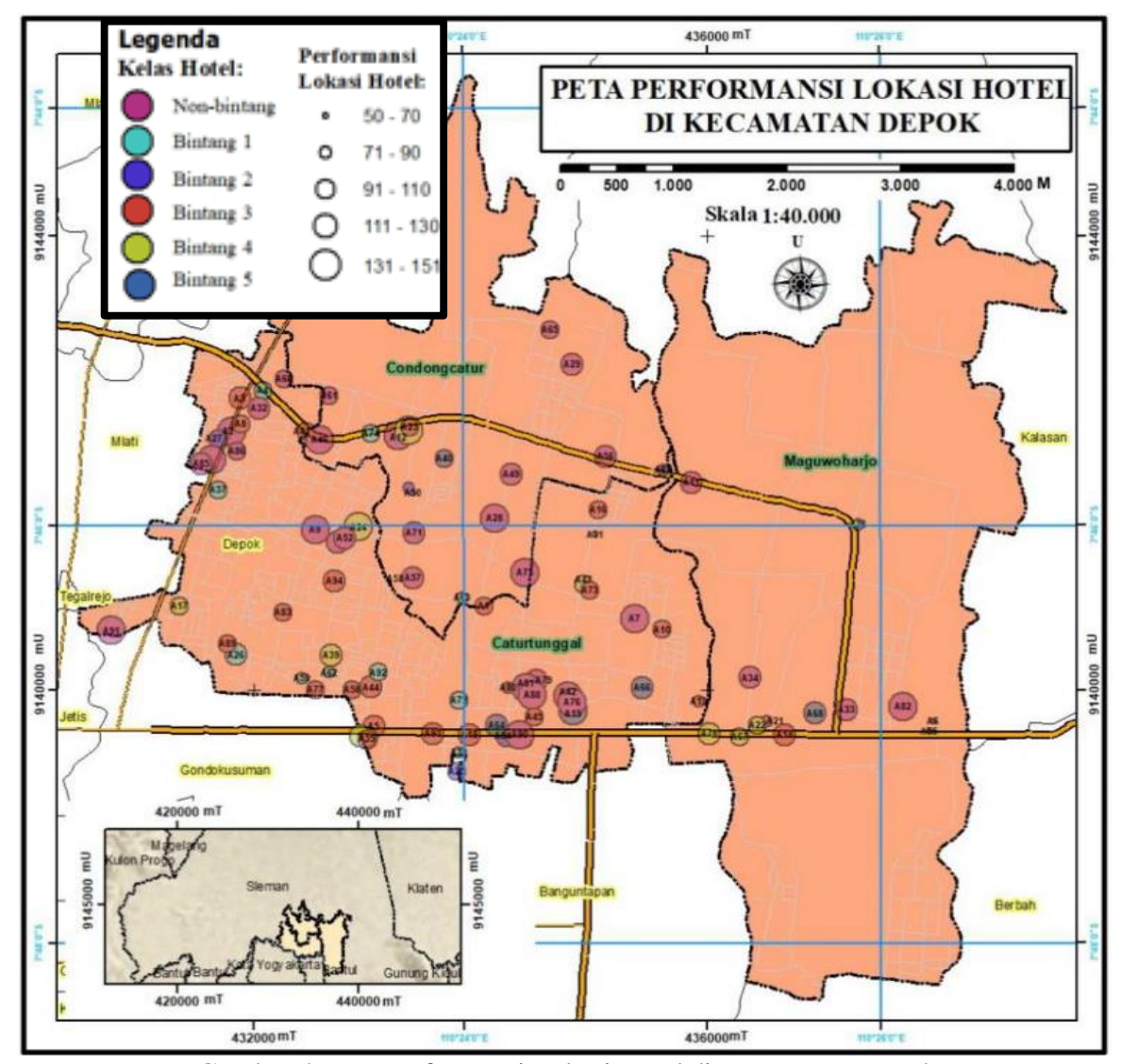

Gambar 4. Peta Performansi Lokasi Hotel di Kecamatan Depok

Berdasarkan Tabel 3, terlihat bahwa hotel yang memiliki performansi tertinggi dengan rentang nilai 131 - 150 terdapat sebanyak 18 hotel dan 83\% dari hotel tersebut merupakan hotel dengan kelas non-bintang. Pengaruh terbesar yang menyebabkan hotel non-bintang memilki nilai tertinggi karena hotel non-bintang berlokasi di lokasi yang diizinkan untuk dilakukan kegiatan hotel yang mengacu pada RDTR (Rencana Detail Tata Ruang) Kecamatan Depok. Lokasi hotel yang sesuai dengan arahan tata ruang memiliki pengaruh yang sangat besar terhadap hasil akhir perhitungan performansi karena berdasarkan ulasan sebelumnya, peraturan tata ruang memiliki bobot tertinggi dibandingkan dengan indikator lain dengan nilai bobot sebesar 9,578. Di samping itu, faktor lain yang menyebabkan sebagian hotel non-bintang memiliki nilai performansi yang 
Jurnal Pendidikan Geografi:

Kajian, Teori, dan Praktik dalam Bidang Pendidikan dan Ilmu Geografi

Tahun 24, Nomor 2, Jun 2019, Hal 85-97

baik adalah karena lokasi hotel non-bintang yang strategis sehingga menyebabkan okupansi hotel tinggi.

Hotel yang memiliki nilai performansi kelas terendah dengan rentang nilai $50-70$ terdapat sebanyak 5 hotel yang mana $60 \%$ dari hotel tersebut merupakan hotel berbintang 1. Berdasarkan hasil perhitungan, hotel berbintang 1 memiliki rentang nilai yang rendah karena banyak hotel berbintang 1 berlokasi di lokasi yang tidak diizinkan untuk melakukan kegiatan perhotelan. Selain itu, hotel berbintang 1 memiliki jumlah fasilitas pelayanan yang sedikit sehingga wisatawan yang menginap hanya 1 hari. Adapun faktor lain yang mempengaruhi nilai performansi akan dibahas pada masing-masing indikator dan variabel sebagai berikut.

Tabel 3. Tabulasi Silang Antara Klasifikasi Nilai Performansi Lokasi dengan Kelas Hotel

\begin{tabular}{|c|c|c|c|c|c|c|c|c|c|c|c|}
\hline \multirow[b]{2}{*}{ Kelas Hotel } & \multicolumn{10}{|c|}{ Klasifikasi Nilai Performansi Lokasi Hotel } & \multirow[t]{2}{*}{ Tota } \\
\hline & $50-70$ & $(\%)$ & $\begin{array}{c}71- \\
90\end{array}$ & $(\%)$ & $\begin{array}{c}91- \\
110\end{array}$ & $(\%)$ & $\begin{array}{c}111- \\
130\end{array}$ & $(\%)$ & $\begin{array}{c}131- \\
150\end{array}$ & $(\%)$ & \\
\hline Non-bintang & 0 & 0 & 0 & 0 & 5 & 15 & 12 & 46 & 15 & 83 & 32 \\
\hline Bintang 1 & 3 & 60 & 5 & 42 & 4 & 12 & 1 & 4 & 0 & 0 & 13 \\
\hline Bintang 2 & 1 & 20 & 3 & 25 & 4 & 12 & 0 & 0 & 0 & 0 & 8 \\
\hline Bintang 3 & 0 & 0 & 3 & 25 & 15 & 45 & 6 & 23 & 0 & 0 & 24 \\
\hline Bintang 4 & 1 & 20 & 1 & 8 & 4 & 12 & 3 & 12 & 2 & 11 & 11 \\
\hline Bintang 5 & 0 & 0 & 0 & 0 & 1 & 3 & 4 & 15 & 1 & 6 & 6 \\
\hline Total & 5 & $\mathrm{i} 100$ & 12 & 100 & 33 & 100 & 26 & 100 & 18 & 100 & 94 \\
\hline
\end{tabular}

Sumber: Hasil Olah Data Peneliti, 2018

Performansi hotel menurut beberapa penelitian memiliki pengaruh terhadap efek aglomerasi lokasi hotel. Menurut Barros (2005) hotel yang berada di lokasi yang mengelompok akan lebih efisien dibandingkan dengan hotel yang berada di luar pola distribusi mengelompok. Pola distribusi hotel yang ada di Kecamatan Depok berdasarkan perhitungan analisis tetangga terdekat. Hubungan antara pola distribusi hotel dan performansi lokasi hotel diperoleh dengan analisis spasial. Persebaran hotel yang ada di Kecamatan Depok didibagi menjadi beberapa sub zona yang dapat dilihat pada Gambar 5. 
Jurnal Pendidikan Geografi:

Kajian, Teori, dan Praktik dalam Bidang Pendidikan dan Ilmu Geografi

Tahun 24, Nomor 2, Jun 2019, Hal 85-97

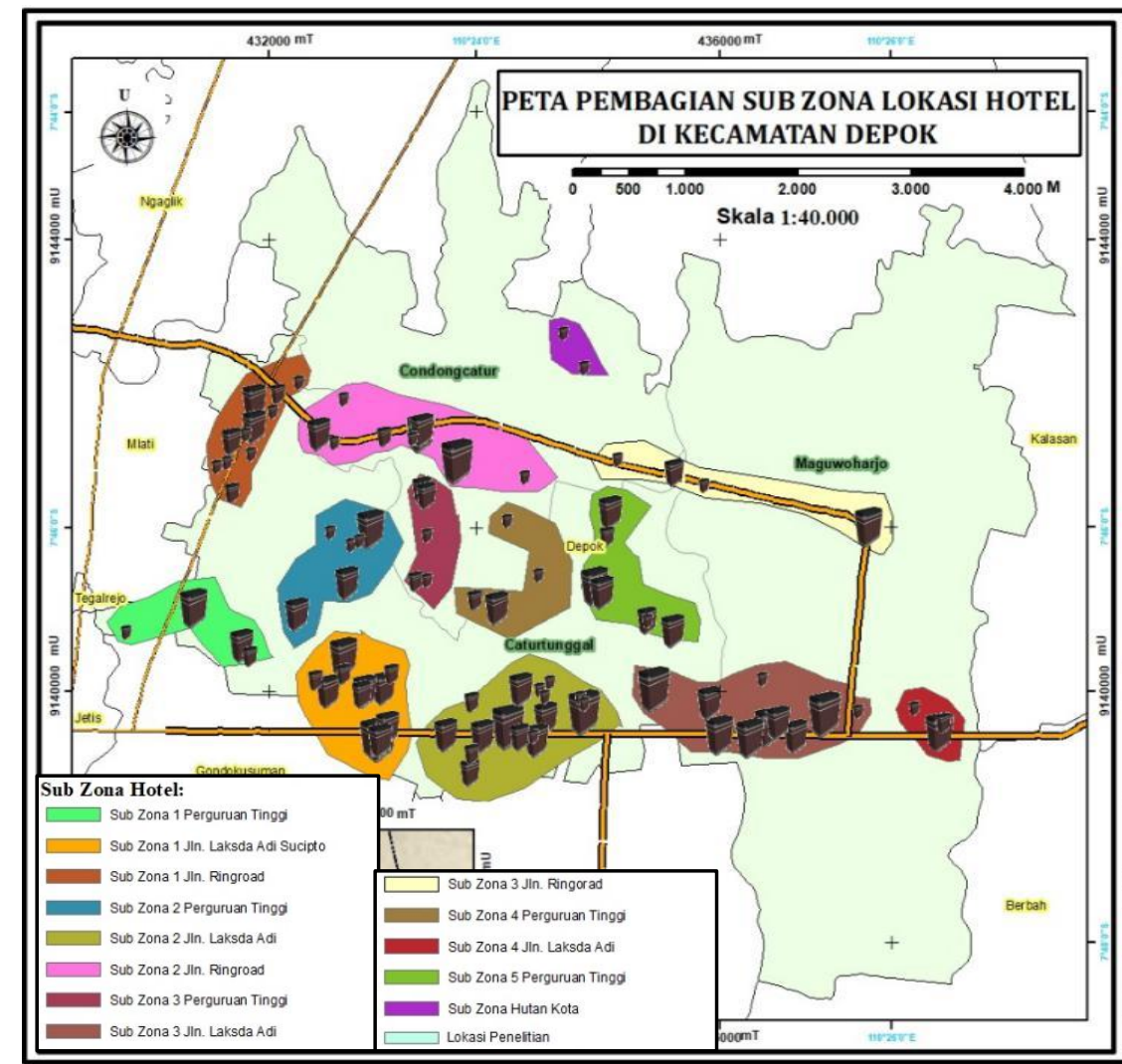

Gambar 5. Peta Pembagian Sub Zona Lokasi Hotel di Kecamatan Depok

Nilai performansi lokasi hotel yang ada di Kecamatan Depok tidak memiliki hubungan dengan pola distribusi hotel tersebut. Hal ini disebabkan karena nilai performansi hotel yang berada di sub zona yang sama rerata memiliki nilai performansi lokasi yang beragam mulai dari nilai yang tertinggi sampai dengan nilai ketegori sedang atau bahkan terdapat hotel dengan nilai yang terendah. Hal ini salah satunya terlihat pada sub zona 2 di Jalan Laksda Adi Sucipto misalnya terdapat 6 hotel yang memiliki rentan nilai 131 - 150 dan juga terdapat 2 hotel yang memiliki rentan nilai 71-90. Tidak adanya hubungan antara pola distribusi hotel dengan nilai akhir dari performansi lokasi hotel disebabkan karena variabel yang digunakan tidak hanya jarak hotel terhadap suatu lokasi tetapi terdapat pula faktor internal sehingga yang membedakan satu hotel dengan hotel lainnya meskipun berdekatan namun nilainya variabel tersebut dapat berbeda misalnya saja pada indikator lama pengunjung yang menginap. Pada indikator tersebut nilai akhir yang dihasilkan antara satu hotel dengan hotel yang berdekatan memiliki nilai yang berbeda karena indikator tersebut memiliki pengaruh terhadap tingkat kepuasan dari masingmasing pelanggan.

Nilai performansi lokasi hotel merupakan nilai akhir yang merupakan hasil akumulasi dari indikator atribut lokasi, indikator peraturan daerah, indikator karakteristik hotel dan indikator jasa publik sekitar hotel. Masing-masing indikator memiliki hubungan yang berbeda dengan pola distribusi hotel. Terdapat hubungan antara pola distribusi hotel dengan hasil akhir perhitungan indikator atribut lokasi. Hal ini terlihat pada Tabel 4. dimana masing-masing sub zona memiliki nilai indikator atribut lokasi dengan nilai yang tidak jauh berbeda. Salah satunya pada sub zona 2 yang berasosiasi dengan Jalan Laksda Adi Sucipto yang terdiri dari 17 hotel yang mana 11 hotel memiliki rentan nilai $16-20$ dan 6 hotel lainnya memiliki nilai $21-25$. Pola distribusi hotel dengan nilai indikator 
Jurnal Pendidikan Geografi:

Kajian, Teori, dan Praktik dalam Bidang Pendidikan dan Ilmu Geografi

Tahun 24, Nomor 2, Jun 2019, Hal 85-97

atribut lokasi memiliki hubungan dengan nilai indikator atribut lokasi karena perhitungan pada indikator atribut lokasi menggunakan jarak hotel dengan objek wisataa, sarana transportasi dan central business services. Sehingga apabila hotel berdekatan satu sama lain maka nilai indikator atribut lokasi pada hotel yang saling berdekatan tersebut memiliki nilai yang hampir sama.

Tabel 4. Tabulasi Silang Antara Klasifikasi Nilai Performansi Lokasi Hotel dengan Kelas Hotel

\begin{tabular}{|c|c|c|c|c|c|c|c|c|c|c|c|c|}
\hline \multirow[b]{2}{*}{ Zona } & \multirow[b]{2}{*}{ Sub Zona } & \multicolumn{10}{|c|}{ Klasifikasi Nilai Jasa Publik Sekitar Hotel } & \multirow{2}{*}{$\begin{array}{l}\text { To- } \\
\text { tal }\end{array}$} \\
\hline & & $\begin{array}{c}1- \\
7\end{array}$ & $\%$ & $\begin{array}{l}8- \\
14\end{array}$ & $\%$ & $\begin{array}{c}15- \\
21\end{array}$ & $\%$ & $\begin{array}{c}22- \\
28\end{array}$ & $\%$ & $\begin{array}{c}29- \\
35\end{array}$ & $\%$ & \\
\hline \multirow[t]{2}{*}{ Hutan Kota } & Sub zona 1 & 0 & 0 & 0 & 0 & 1 & 11 & 1 & 2 & 0 & 0 & 2 \\
\hline & $\begin{array}{c}\text { Sub zona } 1 \text { Jalan Laksda } \\
\text { Adi Sucipto }\end{array}$ & 0 & 0 & 0 & 0 & 0 & 0 & 1 & 2 & 11 & 30 & 12 \\
\hline \multirow{4}{*}{$\begin{array}{l}\text { Jalan Laksda Adi } \\
\text { Sucipto }\end{array}$} & $\begin{array}{c}\text { Sub zona } 2 \text { Jalan Laksda } \\
\text { Adi Sucipto }\end{array}$ & 0 & 0 & 0 & 0 & 0 & 0 & 8 & 19 & 9 & 24 & 17 \\
\hline & $\begin{array}{c}\text { Sub zona } 3 \text { Jalan Laksda } \\
\text { Adi Sucipto }\end{array}$ & 0 & 0 & 1 & 25 & 6 & 67 & 3 & 7 & 0 & 0 & 10 \\
\hline & $\begin{array}{c}\text { Sub zona } 4 \text { Jalan Laksda } \\
\text { Adi Sucipto }\end{array}$ & 2 & $\begin{array}{c}10 \\
0\end{array}$ & 1 & 25 & 0 & 0 & 0 & 0 & 0 & 0 & 3 \\
\hline & Sub zona 1 jalan ringroad & 0 & 0 & 0 & 0 & 0 & 0 & 10 & 24 & 1 & 3 & 11 \\
\hline \multirow{4}{*}{ Jalan Ringroad } & Sub zona 2 jalan ringroad & 0 & 0 & 0 & 0 & 0 & 0 & 8 & 19 & 1 & 3 & 9 \\
\hline & Sub zona 3 jalan ringroad & 0 & 0 & 2 & 50 & 2 & 22 & 0 & 0 & 0 & 0 & 4 \\
\hline & $\begin{array}{c}\text { Sub zona } 1 \text { perguruan } \\
\text { tinggi }\end{array}$ & 0 & 0 & 0 & 0 & 0 & 0 & 2 & 5 & 2 & 5 & 4 \\
\hline & $\begin{array}{c}\text { Sub zona } 2 \text { perguruan } \\
\text { tinggi }\end{array}$ & 0 & 0 & 0 & 0 & 0 & 0 & 2 & 5 & 4 & 11 & 6 \\
\hline \multirow[t]{4}{*}{ Perguruan Tingi } & $\begin{array}{c}\text { Sub zona } 3 \text { perguruan } \\
\text { tinggi }\end{array}$ & 0 & 0 & 0 & 0 & 0 & 0 & 0 & 0 & 5 & 14 & 5 \\
\hline & $\begin{array}{c}\text { Sub zona } 4 \text { perguruan } \\
\text { tinggi }\end{array}$ & 0 & 0 & 0 & 0 & 0 & 0 & 0 & 0 & 4 & 11 & 4 \\
\hline & $\begin{array}{c}\text { Sub zona } 5 \text { perguruan } \\
\text { tinggi }\end{array}$ & 0 & 0 & 0 & 0 & 0 & 0 & 7 & 17 & 0 & 0 & 7 \\
\hline & Total & 2 & $\begin{array}{c}10 \\
0\end{array}$ & 4 & $\begin{array}{c}10 \\
0\end{array}$ & 9 & $\begin{array}{c}10 \\
0\end{array}$ & 42 & $\begin{array}{c}10 \\
0\end{array}$ & 37 & $\begin{array}{c}10 \\
0\end{array}$ & 100 \\
\hline
\end{tabular}

Sumber: Hasil Olah Data Peneliti, 2018

\section{KESIMPULAN}

Berdasarkan hasil penelitian yang telah dilakukan, maka dapat disimpulkan bahwa pola distribusi hotel yang ada di Kecamatan Depok memiliki pola distribusi hotel yang mengelompok dengan nilai z-score sebesar -4,5826486. Secara spasial, pola distribusi hotel terdiri dari 4 (empat) pola yaitu hotel yang berasosiasi dengan Jalan Ringroad, hotel yang berasosiasi dengan perguruan tinggi, hotel yang berasosiasi dengan hutan kota dan hotel yang berasosiasi denngan Jalan Laksda Adi Sucipto. Berdasarkan pola distribusi hotel tersebut maka model kota wisata-sejarah (tourist-historic city model) merupakan model yang sesuai dengan persebaran hotel di Kecamatan Depok.

Berdasarkan perhitungan performansi lokasi hotel yang menggunakan indikator atribut lokasi, karakteristik hotel, peraturan daerah dan indikator jasa publik sekitar hotel maka hotel yang memiliki nilai performansi tertinggi berada di Jalan Laksda Adi Sucipto dengan kelas hotel berupa hotel non-bintang. Secara umum tidak ada hubungan antara pola distribusi hotel dengan nilai peformansi lokasi hotel. Setelah ditelaah lebih dalam terdapat hubungan antara pola distribusi hotel dengan nilai akhir dari indikator atribut lokasi dan jasa publik sekitar hotel. Di samping itu, tidak terdapat hubungan antara pola distribusi hotel dengan nilai akhir dari indikator peraturan daerah dan karakteristik hotel.

Melihat dari hasil penelitian yang telah dilakukan, terdapat beberapa saran yang diberikan oleh peneliti, yaitu: 
1. Penelitian ini secara umum hanya melihat kajian performansi lokasi hotel yang ada di Kecamatan Depok penelitian selanjutnya sebaiknya mencakup semua hotel yang ada di Provinsi Daerah Istimewa Yogyakarta (DIY).

2. Bagi pengelola dan investor hotel dalam pemilihan lokasi hotel sebaiknya mempertimbangkan aspek tata ruang karena merupakan salah satu indikator terpenting dalam tahap memperoleh perizinan.

3. Bagi pengelola hotel non-bintang yang berada di sepanjang Jalan Ringroad dan yang berasosiasi dengan perguruan tinggi sebaiknya melakukan peremajaan pembangunan seperti penambahan fasilitas hotel dan melakukan branding dan melakukan kerjasama dengan agen travel.

\section{DAFTAR RUJUKAN}

Antariksa, Arviandi. (2015). Dampak perkembangan hotel terhadap perkembangan kawasan di sekitarnya di kawasan perkotaan Yogyakarta. Yogyakarta: S1 Arsitektur UGM (tidak dipublikasikan).

Badan Pusat Statistika. (2011). Direktori hotel dan akomodasi lain Daerah Istimewa Yogyakarta 2011. Yogyakarta: Badan Pusat Statistika Provinsi D.I Yogyakarta.

Badan Pusat Statistika. (2016). Direktori hotel dan akomodasi lain Daerah Istimewa Yogyakarta 2016. Yogyakarta: Badan Pusat Statistika Provinsi D.I Yogyakarta.

Badan Pusat Statistika. (2016). Provinsi Daerah Istimewa Yogyakarta 2016. Yogyakarta: Badan Pusat Statistika Provinsi D.I Yogyakarta.

Barros, C.P. (2005). Evaluating the efficiency of a small hotel chain with a Malmquist productivity index. International Journal of Tourism Research 7 (3), 173-184.

B.L. MacCarthy, W. Atthirawong. (2003). Factors affecting location decisions in international operations - a Delphi study. International Journal of Operations \& Production Management Vol. 23 Issue: 7, 794-818.

Hagget, Peter. (1972). Geography a modern synthesis. London: Harper dan Row.

Hariyanto \& Tukidi. (2007). Konsep pengembangan wilayah dan penataan ruang Indonesia di era otonomi daerah. Jurnal Geografi, 1-10.

Inskeep, Edward. (1991). Tourism planning. New York: Van Nostran.

Irawan, Popi \& Baiquni, M. (2011). Kajian indikator pariwisata berkelanjutan di kawasan wisata Pantai Parantritis, Kabupaten Bantul, Daerah Istimewa Yogyakarta. Jurnal Kepariwisataan Indonesia Vol 6 nomor 3.

Muta'ali, Luthfi. (2015). Teknik analisis regional untuk perencanaan wilayah, tata ruang dan lingkungan. Yogyakarta: Badan Penerbit Fakultas Geografi (BPFG) Universitas Gadjah Mada.

Newell, Gramae \& Seabrook, Ross. (2005). Factors influencing hotel investment decision making. Journal of Property Investment and Finance Vol. 24 Issue: 4, 279-294.

Piero-Signes, Angel. Etc. (2014). The effect of tourism clusters on U.S. hotel performance. Cornell Hospitality Quarterly, 1 - 13.

Poldrugovac, Katarina., Tekavcic, Metka., \& Jankovic, Sandra. (2017). Efficiency in the hotel industry: an empirical examination of the most influential factors. Economic Research-Ekonomska Istrazivanja, 583-597.

Peraturan Walikota Yogyakarta. (2016). Pengendalian Pembangunan Hotel.

Rustiadi, Ernan., Hakim, Saeful., Sunsun., \& Panuju, Dyah R. (2009). Perencanaan dan pengembangan wilayah. Jakarta: Yayasan Pustaka Obor Indonesia.

Saracli, Oktay \& Emir, Oktay. (2015). Determination of the thermal hotel location: application of analytic hierarchy process. Tourism and Hospitality Management Vol. 20. No 1 . 
Jurnal Pendidikan Geografi:

Kajian, Teori, dan Praktik dalam Bidang Pendidikan dan Ilmu Geografi

Tahun 24, Nomor 2, Jun 2019, Hal 85-97

Shoval, N., McKercher, B., Ng, E., Birenboim, A. (2011). Hotel location and touristactivity in cities. Annals of Tourism Research 38 (4), 1594-1612.

Timothy, Dallen J., \& Wall, Geoffrey. (1997). Selling to tourists Indonesian Street Vendors. Annals of tourism research Vol 24 No 2, $322-340$.

Yang, Yang., Wong, Kevin K.F., \& Wang, Tongkun. (2012). How do hotels choose their location? Evidence from hotels in Beijing. International Journal of Hospitality Management 31, 675-685.

Yang, Yang., Luo, Hao., \& Law, Rob. (2014). Theoretical, empirical, and operational models in hotel location research. International Journal Of Hospitality Management 36, 209- 220. 